Original Paper

\title{
Implementasi Pendekatan Kontekstual untuk Meningkatkan Prestasi Belajar Matematika Siswa Kelas V SDN 1 Sesela Kecamatan Gunungsari Kabupaten Lombok Barat Tahun Pelajaran 2018/2019
}

\author{
Mastari ${ }^{1 *}$ \\ ${ }^{1}$ Sekolah Dasar Negeri 1 Sesela Kecamatan Gunungsari Kabupaten Lombok Barat, Indonesia.
}

\author{
*Corresponding Author: \\ Mastari, Sekolah Dasar \\ Negeri 1 Sesela \\ Kecamatan Gunungsari \\ Kabupaten Lombok Barat, \\ Indonesia; \\ Email: \\ hj.mastari@gmail.com
}

\begin{abstract}
Abstrak: Penelitian ini dilakukan dengan tujuan Mengetahui adanya peningkatan prestasi belajar melalui impelementasi pendekatan konstektual pada siswa Kelas V SDN 1 Sesela Kecamatan Gunungsari Kabupaten Lombok Barat. Subyek penelitian adalah siswa kelas V SDN 1 Sesela. Data-data yang diperlukan dalam penelitian ini diperoleh melalui observasi pengolahan metode pembelajaran demonstrasi, observasi aktivitas siswa dan guru, dan tes formatif. Pada penelitian ini menggunakan teknik analisis deskriptif kualitatif, yaitu suatu metode penelitian yang bersifat menggambarkan kenyataan atau fakta sesuai dengan data yang diperoleh dengan tujuan untuk mengetahui prestasi belajar yang dicapai siswa juga untuk memperoleh respon siswa terhadap kegiata pembelajaran serta aktivitas siswa selama proses pembelajaran. Hasil penelitian menunjukkan bahwa: 1) Pembelajaran dengan pendekatan kontekstual memiliki dampak positif dalam meningkatkan prestasi belajar siswa yang ditandai dengan peningkatan ketuntasan belajar siswa dalam setiap siklus, yaitu siklus I (52\%) dan siklus II (87\%); 2) Penerapan pendekatan kontekstual mempunyai pengaruh positif, yaitu dapat meningkatkan motivasi belajar siswa yang ditunjukan dengan hasil wawancara dengan sebagian siswa, rata-rata jawaban siswa menyatakan bahwa siswa tertarik dan berminat dengan pendekatan kontekstual sehingga mereka menjadi termotivasi untuk belajar.
\end{abstract}

Kata kunci: Implementasi; Pendekatan konstektual; Prestasi belajar.

\section{Pendahuluan}

Pendidikan adalah suatu bentuk perwujudan kebudayaan manusia yang dinamis dan sarat perkembangan yang dilakukan secara sadar dan sengaja untuk mengembangkan kognitif, afektif, dan psikomotor peserta didik. Program pendidikan melibatkan sejumlah komponen yang bekerjasama dalam sebuah proses untuk mencapai tujuan yang diprogramkan (Muliani, dkk, 2013).

Pendidikan menjadi sarana yang sangat menunjang kehidupan masyarakat luas sedangkan yang kita rasakan saat ini adalah turunya mutu pendidikan, pendidikan memang telah menjadi penopang dalam meningkatkan sumber daya manusia di Indonesia untuk membangun bangsa yang lebih baik dan berprestasi (Chaqiqi, 2014).
Oleh karena itu, kita seharusnya dapat meningkatkan sumber daya negara Indonesia agar tidak kalah bersaing dengan sumber daya manusia di negara-negara lain.

Sejauh ini pendidikan kita masih didominasi oleh pandangan bahwa pengetahuan sebagai perangkat fakta-fakta yang harus dihapal. Kelas masih berfokus pada guru sebagai sumber utama pengetahuan, kemudian ceramah menjadi pilihan utama strategi belajar. Untuk itu diperlukan strategi belajar baru yang lebih memperdayakan siswa. Sebuah strategi belajar yang tidak mengharuskan siswa menghapal fakta-fakta, tetapi sebuah strategi yang mendorong siswa mengkontruksikan pengetahuan dibenak mereka sendiri. Melalui landasan filosofi kontruktivisme, contextual teaching and learning (CTL) siswa diharapkan belajar melalui mengalami bukan menghapal. 
Guru memiliki peranan yang sangat penting dalam pembelajaran termasuk pembelajaran mata pelajaran matematika. Untuk itu seorang guru perlu mencari strategi alternatif dalam menumbuhkan minat siswa agar mau belajar dengan gembira (tanpa merasa dipaksa), sehingga dapat menimbulkan percaya diri pada siswa, yang pada akhirnya mereka dapat mengembangkan kemampuan yang telah ada tanpa mereka sadari.

Tampaknya menggali kemampuan siswa dengan cara menumbuhkembangkan kemampuan yang telah ada belum pernah dilakukan oleh guru SDN 1 Sesela Kecamatan Gunungsari Kabupaten Lombok Barat, sehingga proses pembelajaran masih terlihat monoton dengan penggunakan metode pembelajaran yang sama dengan sebelumnya.

Sekolah Dasar (SD) memegang peranan yang sangat penting dalam pendidikan. Keberhasilan siswa di SD sangat berpengaruh terhadap keberhasilannya di sekolah lanjutan. Menurut informasi dari guru SDN 1 Sesela diperoleh bahwa rata-rata prestasi belajar matematika siswa kelas V masih rendah. Dalam proses pembelajarannya, guru berupaya memberikan penjelasan materi secara lengkap. Dalam hal ini siswa cendrung dituntut untuk mengikuti contoh yang telah diberikan oleh guru. Tentunya pembelajaran seperti ini tidak relevan dengan tuntutan Kurikulum Berbasis Kompetensi (KBK).

Dari kenyataan ini jelaslah guru SDN 1 Sesela perlu dibantu dengan melibatkan yang bersangkutan pada suatu penelitian tindakan kelas dengan maksud agar disamping guru memperoleh pengalaman langsung dalam melakukan pembelajaran yang sesuai dengan tuntutan KBK, juga dapat mengembangkan kompetensi siswa sesuai dengan yang digariskan dalam kurikulum.

Selama ini, dalam proses pembelajaran guru memulai dengan menjelaskan memberi contoh latihan soal. Jadi siswa secara langsung diberikan rumus-rumus matematika tanpa diberi kesempatan untuk menemukan sendiri. Berbeda halnya dengan pembelajaran yang berorientasi pada kurikulum berbasis kompetensi (KBK), pembelajaran hendaknya diawali dari dunia nyata dan rumus diharapkan ditemukan oleh siswa sendiri. Salah satu strategi yang harus dilakukan supaya proses pembelajaran seperti sebelumnya tidak terulang kembali adalah menggunakan pendekatan pembelajaran yang baik yaitu pendekatan contextual teaching and learning (CTL).

Pada pembelajaran CTL guru tidak mengharuskan siswa menghapal fakta-fakta tetapi guru hendaknya mendorong siswa untuk mengkontruksi pengetahuan dibenak mereka sendiri. Melalui CTL siswa diharapkan belajar melalui 'mengalami' bukan 'menghapal'. Dalam pembelajaran, guru perlu memahami konsepsi awal yang dimiliki siswa dan mengaitkan dengan konsep yang akan dipelajari.

Matematika sebagai salah satu mata pelajaran yang diajarkan di sekolah dasar memiliki peranan penting bagi kehidupan sehari-hari siswa. Sundayana (2014) mengemukakan matematika merupakan salah satu komponen dari serangkaian mata pelajaran yang mempunyai peranan penting dalam pendidikan. Sejalan dengan pendapat tersebut maka dibutuhkan pemahaman yang baik mengenai pembelajaran matematika. Pemahaman tersebut akan diperoleh apabila pembelajaran matematika dapat bermakna bagi siswa. Sumantri (2015) mengemukakan bahwa pembelajaran matematika di sekolah akan jadi lebih bermakna bila guru mengaitkannya dengan apa yang telah diketahui oleh siswa dan pengertian tentang ide matematika dapat dibangun melalui sekolah, jika siswa secara aktif mengaitkan pengetahuannya.

Namun kenyataan banyaknya keluhan dari siswa tentang pelajaran matematika yang sulit, tidak menarik, dan membosankan. Keluhan ini secara langsung maupun tidak langsung akan sangat berpengaruh terhadap hasil belajar matematika siswa pada setiap jenjang pendidikan. Kristian, (2018) menyatakan bahwa salah satu faktor yang menyebabkan keluhan dari siswa tentang pelajaran matematika yang sulit, tidak menarik, dan membosankan adalah guru yang hanya selalu menggunakan model pembelajaran konvensional, sehingga siswa-siswa merasakan kejenuhan. Dalam hal ini siswa bersifat pasif, dan guru sangat aktif dalam pembelajaran. Padahal dalam proses pembelajaran yang seharusnya lebih aktif adalah siswa. Siswa harus dibuat aktif menemukan suatu konsep sehingga mereka dapat belajar dengan optimal.

Berdasarkan latar belakang di atas maka peneliti terdorong untuk melakukan penelitian tindakan kelas yang berjudul "Implementasi Pendekatan Kontekstual untuk Meningkatkan Prestasi Belajar Matematika Siswa Kelas V SDN 1 
Sesela Kecamatan Gunungsari Kabupaten Lombok Barat Tahun Pelajaran 2018/2019”.

\section{Metode}

Penelitian ini menggunakan Penelitian Tindakan Kelas (PTK). Menurut Mukhlis (2000) PTK adalah suatu bentuk kajian yang bersifat reflektif oleh pelaku tindakan yang dilakukan untuk meningkatkan kemantapan rasional dari tindakan mereka dalam melaksanakan tugas, memperdalam pemahaman terhadap tindakan-tindakan yang dilakukan itu, serta memperbaiki kondisi dimana praktek pembelajaran tersebut dilakukan. Lebih lanjut lagi Mukhlis (2000) PTK adalah suatu bentuk kajian yang bersifat sistematis reflektif oleh pelaku tindakan untuk memperbaiki kondisi pembelajaran yang dilakukan. Adapun tahap-tahap penelitian yang dilakukan dapat dilihat pada Gambar 1 berikut.

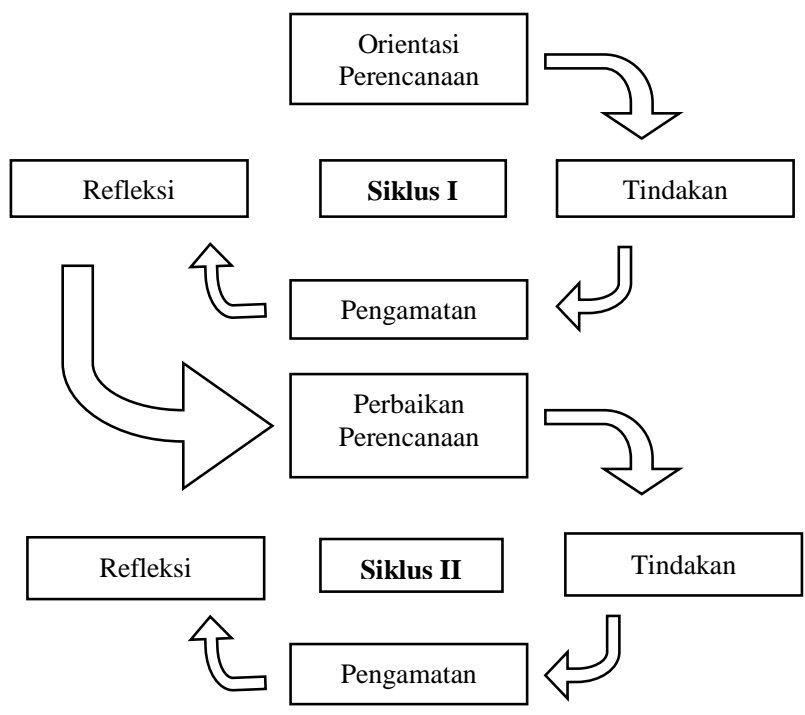

Gambar 1: Model Penelitian Tindakan Kelas Arikunto, (2010).

Tempat penelitian adalah tempat yang digunakan dalam melakukan penelitian untuk memperoleh data yang diinginkan. Penelitian ini bertempat di SDN 1 Sesela Kecamatan Gunungsari Kabupaten Lombok Barat Tahun Pelajaran 2018/2019. Waktu penelitian adalah waktu berlangsungnya penelitian atau saat penelitian ini dilangsungkan. Penelitian ini dilaksanakan pada bulan April sampai Mei 2018 semester genap.
Subyek penelitian adalah siswa-siswi kelas V SDN 1 Sesela Kecamatan Gunungsari Kabupaten Lombok Barat Tahun Pelajaran 2018/2019 pada mata pelajaran matematika materi pecahan.

Data-data yang diperlukan dalam penelitian ini diperoleh melalui observasi pengolahan metode pembelajaran demonstrasi, observasi aktivitas siswa dan guru, dan tes formatif.

\section{Hasil dan Pembahasan}

Sebelum melaksanakan pengambilan data melalui instrumen penelitian berupa tes dan mendapatkan tes yang baik, maka data tes tersebut diuji dan dianalisi. Uji coba dilakukan pada siswa di luar sasaran penelitian. Analisis tes yang dilakukan meliputi validitas, reliabilitas, dan analisis daya beda. Validitas butir soal dimaksudkan untuk mengetahui kelayakan tes sehingga dapat digunakan sebagai instrument dalam penelitian ini. Dari perhitungan 45 soal diperoleh 15 soal tidak valid dan 30 soal valid. Hasil dari validitas soal-soal dirangkum dalam Tabel 1 .

Tabel 1. Soal Valid dan Tidak Valid Tes Formatif Siswa

\begin{tabular}{ll}
\hline Soal Valid & Soal Tidak Valid \\
\hline $1,2,5,6,7,9,10,11,12,13$, & $3,4,8,15,16,18,20$, \\
$14,17,19,21,23,25,26,27$, & $22,24,31,32,33,34$, \\
$28,29,30,36,37,38,39,41$, & 35,40, \\
$42,43,44,45$ & \\
\hline
\end{tabular}

Soal-soal yang telah memenuhi syarat validitas diuji reliabilitasnya. Dari hasil perhitungan diperoleh koefisien reliabilitas $r_{11}$ sebesar 0,775 . Harga ini lebih besar dari harga $r$ product moment. Untuk jumlah siswa $(\mathrm{N}=22)$ dengan $\mathrm{r}(95 \%)=$ 0,423 . Dengan demikian soal-soal tes yang digunakan telah memenuhi syarat reliabilitas. Taraf kesukaran digunakan untuk mengetahui tingkat kesukaran soal. Hasil analisis menunjukkan dari 45 soal yang diuji terdapat 20 soal mudah, 15 soal sedang, 10 soal sukar.

Analisis daya pembeda dilakukan untuk mengetahui kemampuan soal dalam membedakan siswa yang berkemampuan tinggi dengan siswa yang berkemampuan rendah. Dari hasil analisis daya pembeda diperoleh soal yang berkriteria jelek sebanyak 15 soal, berkriteria cukup 20 soal, berkreteria baik 10 soal. Dengan demikian soal-soal tes yang digunakan telah memenuhi syara-syarat 
validitas, reliabilitas, taraf kesukaran, dan daya pembeda.

Setalah dilakukan uji validasi, reliabilitas dan analisis daya beda, dilakukan analisis data penelitian persiklus. Pada siklus I, tahap perencanaan dilakukan dengan mempersiapkan perangkat pembelajaran yang terdiri dari rencana pelajaran 1, LKS 1, soal tes formatif 1, dan alat-alat pengajaran yang mendukung. Pada tahap kegiatan dan pelaksanaan, kegiatan belajar mengajar untuk dilaksanakan pada tanggal 13 April 2018 di kelas V dengan jumlah siswa 23 siswa. Dalam hal ini peneliti bertindak sebagai guru. Adapun proses belajar mengajar mengacu pada rencana pelajaran yang telah dipersiapkan. Pengamatan (observasi) dilaksanakan bersamaan dengan pelaksanaan belajar mengajar.

Pada akhir proses belajar mengajar siswa diberi tes formatif I dengan tujuan untuk mengetahui tingkat keberhasilan siswa dalam proses belajar mengajar yang telah dilakukan. Adapun data hasil penelitian pada siklus I seperti pada Tabel 2 dan Tabel 3:

Tabel 2. Hasil Tes Formatif Siswa Pada Siklus I

\begin{tabular}{llllll}
\hline No. Urut & Nilai & Keterangan & No. Urut & Nilai & Keterangan \\
\hline 1 & 60 & Tidak Tuntas & 13 & 60 & Tidak Tuntas \\
2 & 60 & Tidak Tuntas & 14 & 50 & Tidak Tuntas \\
3 & 70 & Tuntas & 15 & 70 & Tuntas \\
4 & 60 & Tidak Tuntas & 16 & 80 & Tuntas \\
5 & 80 & Tuntas & 17 & 70 & Tuntas \\
6 & 60 & Tidak Tuntas & 18 & 90 & Tuntas \\
7 & 70 & Tuntas & 19 & 60 & Tidak Tuntas \\
8 & 70 & Tuntas & 20 & 60 & Tidak Tuntas \\
9 & 60 & Tidak Tuntas & 21 & 70 & Tuntas \\
10 & 80 & Tuntas & 22 & 70 & Tuntas \\
11 & 50 & Tidak Tuntas & 23 & 60 & Tidak Tuntas \\
12 & 80 & Tuntas & & & \\
\hline
\end{tabular}

Tabel3. Rekapitulasi Hasil Tes Siklus I

\begin{tabular}{lll}
\hline No & Uraian & $\begin{array}{l}\text { Hasil } \\
\text { Siklus I }\end{array}$ \\
\hline 1 & Nilai rata-rata tes formatif & 66,95 \\
2 & Jumlah siswa yang tuntas belajar & 12 \\
3 & Persentase ketuntasan belajar & $52 \%$ \\
\hline
\end{tabular}

Dari Tabel 2 dan Table 3 di atas dapat dijelaskan bahwa dengan menerapkan pendekatan kontekstual pada pembelajaran matematika diperoleh nilai rata-rata prestasi belajar siswa adalah 66,95 dan ketuntasan belajar mencapai 52\% atau ada 12 siswa dari 23 siswa sudah tuntas belajar. Hasil tersebut menunjukkan bahwa pada siklus pertama secara klasikal siswa belum tuntas belajar, karena siswa yang memperoleh nilai $\geq 65$ hanya sebesar $52 \%$ lebih kecil dari persentase ketuntasan yang dikehendaki yaitu sebesar $85 \%$. Hal ini disebabkan karena siswa masih merasa baru dan belum mengerti apa yang dimaksudkan dan digunakan guru dengan menerapkan pendekatan kontekstual.
Pada siklus II, tahap perencanaan dilakukan dengan mempersiapkan perangkat pembelajaran yang terdiri dari rencana pelajaran 2, LKS 2, soal tes formatif II, dan alat-alat pengajaran yang mendukung. Pada tahap tahap kegiatan dan pelaksanaan kegiatan belajar mengajar untuk siklus II dilaksanakan pada tanggal 20 April 2009 di kelas $\mathrm{V}$ dengan jumlah siswa 22 siswa. Dalam hal ini peneliti bertindak sebagai guru. Adapun proses belajar mengajar mengacu pada rencana pelajaran dengan memperhatikan revisi pada siklus I, sehingga kesalahan atau kekurangan pada siklus I tidak terulang lagi pada siklus II. Pengamatan (observasi) dilaksanakan bersamaan dengan pelaksanaan belajar mengajar.

Pada akhir proses belajar mengajar siswa diberi tes formatif II dengan tujuan untuk mengetahui tingkat keberhasilan siswa selama proses belajar mengajar yang telah dilakukan. Instrument yang digunakan adalah tes formatif II. Adapun data hasil penelitian pada siklus II seperti Tabel 4 dan Tabel 5. 
Tabel 4. Hasil Tes Formatif Siswa Pada Siklus II

\begin{tabular}{llllll}
\hline No. Urut & Nilai & Keterangan & No. Urut & Nilai & Keterangan \\
\hline 1 & 80 & Tuntas & 13 & 80 & Tuntas \\
2 & 80 & Tuntas & 14 & 50 & Tidak Tuntas \\
3 & 70 & Tuntas & 15 & 70 & Tuntas \\
4 & 80 & Tuntas & 16 & 90 & Tuntas \\
5 & 80 & Tuntas & 17 & 70 & Tuntas \\
6 & 60 & Tidak Tuntas & 18 & 90 & Tuntas \\
7 & 70 & Tuntas & 19 & 80 & Tuntas \\
8 & 70 & Tuntas & 20 & 70 & Tuntas \\
9 & 80 & Tuntas & 21 & 90 & Tuntas \\
10 & 80 & Tuntas & 22 & 90 & Tuntas \\
11 & 60 & Tidak Tuntas & 23 & 70 & Tuntas \\
12 & 80 & Tuntas & & & \\
\hline
\end{tabular}

Tabel 5. Rekapitulasi Hasil Tes Siklus II

\begin{tabular}{lll}
\hline No & Uraian & $\begin{array}{l}\text { Hasil Siklus } \\
\text { II }\end{array}$ \\
\hline 1 & Nilai rata-rata tes formatif & 75,65 \\
2 & Jumlah siswa yang tuntas belajar & 20 \\
3 & Persentase ketuntasan belajar & $87 \%$ \\
\hline
\end{tabular}

Dari tabel 4 dan tabel 5 di atas diperoleh nilai rata-rata prestasi belajar siswa adalah 75,65 dan ketuntasan belajar mencapai $87 \%$ atau ada 20 siswa dari 23 siswa sudah tuntas belajar. Hasil ini menunjukkan bahwa pada siklus II ini ketuntasan belajar secara klasikal telah megalami peningkatan dari siklus I sehingga secara klasikal siswa sudah tuntas. Adanya peningkatan hasil belajar siswa ini karena setelah guru menginformasikan bahwa setiap akhir pelajaran akan selalu diadakan tes sehingga pada pertemuan berikutnya siswa lebih termotivasi untuk belajar. Selain itu siswa juga sudah mulai mengerti apa yang dimaksudkan dan diinginkan guru dengan menerapkan pendekatan kontekstual dalam pembelajaran matematika.

Pada tahap refleksi dikaji apa yang telah terlaksana dengan baik maupun yang masih kurang baik dalam proses belajar mengajar dengan penerapan pendekatan kontekstual. Dari data-data yang telah diperoleh dapat duraikan sebagai berikut: 1) Selama proses belajar mengajar guru telah melaksanakan semua pembelajaran dengan baik. Meskipun ada beberapa aspek yang belum sempurna, tetapi persentase pelaksanaannya untuk masing-masing aspek cukup besar. 2) Berdasarkan data hasil pengamatan diketahui bahwa siswa aktif selama proses belajar berlangsung. 3) Kekurangan pada siklus I sudah mengalami perbaikan dan peningkatan sehingga menjadi lebih baik pada siklus II. 4) Hasil belajar siswa pada siklus II mencapai ketuntasan.

Pada siklus II guru telah menerapkan pendekatan kontekstual dengan baik dan dilihat dari aktivitas siswa serta hasil belajar siswa pelaksanaan proses belajar mengajar sudah berjalan dengan baik. Maka tidak diperlukan revisi terlalu banyak, tetapi yang perlu diperhatikan untuk tindakan selanjutnya adalah memaksimalkan dan mempertahankan apa yang telah ada dengan tujuan agar pada pelaksanaan proses belajar mengajar selanjutnya penerapan pendekatan kontekstual yang dilaksanakan dapat meningkatkan proses belajar mengajar sehingga tujuan pembelajaran dapat tercapai.

Melalui hasil peneilitian ini menunjukkan bahwa pendekatan kontekstual dalam pembelajaran matematika memiliki dampak positif dalam meningkatkan prestasi belajar siswa. Hal ini dapat dilihat dari semakin mantapnya pemahaman siswa terhadap materi yang disampaikan guru (ketuntasan belajar meningkat dari sklus I, dan II,) yaitu masing-masing 52\%, dan $87 \%$. Pada siklus II ketuntasan belajar siswa secara klasikal telah tercapai.

Berdasarkan analisis data, diperoleh aktivitas siswa dalam proses pembelajaran dengan pendekatan kontekstual dalam setiap siklus mengalami peningkatan. Hal ini berdampak positif terhadap prestasi belajar siswa yaitu dapat ditunjukkan dengan meningkatnya nilai rata-rata siswa pada setiap siklus yang terus mengalami peningkatan.

Berdasarkan analisis data, diperoleh aktivitas siswa dalam proses pembelajaran matematika materi pecahan yang paling dominan adalah bekerja dengan menggunakan alat/media, mendengarkan/ 
memperhatikan penjelasan guru, dan diskusi antar siswa/antara siswa dengan guru. Jadi dapat dikatakan bahwa aktivitas siswa dapat dikategorikan aktif.

Sedangkan untuk aktivitas guru selama pembelajaran telah melaksanakan langah-langkah pembelajaran pendekatan kontekstual dengan baik. Hal ini terlihat dari aktivitas guru yang muncul di antaranya aktivitas membimbing dan mengamati siswa dalam mengerjakan kegiatan LKS/menemukan konsep, menjelaskan/melatih menggunakan alat, memberi umpan balik/evaluasi/tanya jawab dimana prosentase untuk aktivitas di atas cukup besar.

\section{Kesimpulan}

Dari hasil kegiatan pembelajaran yang telah dilakukan selama tiga siklus, dan berdasarkan seluruh pembahasan serta analisis yang telah dilakukan dapat disimpulkan sebagai berikut: 1) Pembelajaran dengan pendekatan kontekstual memiliki dampak positif dalam meningkatkan prestasi belajar siswa yang ditandai dengan peningkatan ketuntasan belajar siswa dalam setiap siklus, yaitu siklus I (52\%) dan siklus II (87\%). 2) Penerapan pendekatan kontekstual mempunyai pengaruh positif, yaitu dapat meningkatkan motivasi belajar siswa yang ditunjukan dengan hasil wawancara dengan sebagian siswa, rata-rata jawaban siswa menyatakan bahwa siswa tertarik dan berminat dengan pendekatan kontekstual sehingga mereka menjadi termotivasi untuk belajar.

\section{Daftar Pustaka}

Arikunto, S. 2010. Dasar-dasar Evaluasi Pendidikan. Jakarta: Bumi Aksara.

Mukhlis, A. 2000. Penelitian Tindakan Kelas. Makalah Panitia Pelatihan Penulisan Karya Ilmiah untuk Guru-guru se-Kabupaten Tuban. http://contextual.org diakses tanggal 15 April 2018

Sumantri. 2015. Strategi Pembelajaran. Jakarta: Kharisma Putra Utama

Sundayana, Rostina. 2014. Statistika Penelitian Pendidikan. Bandung: Alfabeta

Kristian, A. 2018. Pengaruh Model Pembelajaran Contextual Teaching and Learning (Ctl)
Terhadap Hasil Belajar Matematika Siswa Kelas IV SD Negeri Langung Kabupaten Aceh Barat. BINA GOGIK, 5(2). Pp. 13-24

Muliani, N. N., I Kt. Adnyana Putra, I.B. Surya Manuaba. 2013. Pengaruh Pendekatan Contextual Teaching and Learning (CTL) Berbantuan Media Gambar Seri Terhadap Keterampilan Menulis Deskripsi Bahasa Indonesia. Mimbar PGSD Undiksa. 1(1). Pp. 1-10

Chaqiqi, A. 2013. Pengaruh Pendekatan Contextual Teaching and Learning (CTL) Terhadap Hasil Belajar Mata Pelajaran Matematika Materi Garis dan Sudut Pada Siswa Kelas VII Di SMPN 16 Surabaya. Jurnal Mahasiswa Teknologi Pendidikan. 5(1). pp. $1-9$ 